\title{
Increased gastric emptying induced by Helicobacter heilmannii type 1 infection in rats
}

\author{
IVANA DUVAL-ARAUJO, DULCIENE M. DE MAGAL-ÃES QUEIROZ*, ANDERSON G. P. \\ MAGNAGO*, CARLOS J. R. SIMAL†, VIVIANE S. P. MARINO†, SIMONE D. CARVALHO*, \\ LEONARDO A. DA SILVA MACHADO and DAIRTON MIRANDA* \\ * Laboratory of Research in Bacteriology, Postgraduate Surgery Laboratory, Medical School and $\uparrow$ Medicine \\ Nuclear Service, University Hospital, Universidade Federal de Minas Gerais, Brazil
}

\begin{abstract}
The association between Helicobacter pylori infection and gastric motility abnormalities is still controversial, partly because of the lack of an appropriate animal model. $H$. heilmannii type 1 (Hh1), a spiral bacterium that infects the stomach of both man and pigs, easily colonises and induces an inflammatory response in the gastric mucosa of rodents. For these reasons, the present study investigated the relationship between gastric motility in rats experimentally infected with $\mathrm{Hh1}$ and correlated the results with serum gastrin and gastric somatostatin concentrations, as these hormones seem to be involved in gastric motility. Ten rats were inoculated with gastric mucus from an Hh1positive pig and 10 animals with gastric mucus from an Hh1-negative pig (control group). After 56 days, gastric emptying was studied in vivo by scintigraphy. The animals were then killed, blood samples were collected for serum gastrin measurement, strips of the gastric wall were obtained for an in-vitro motor study and fragments of the gastric antrum were obtained for somatostatin content evaluation, Hh1 diagnosis and histological study. There was a significant increase in gastric emptying in the test group compared with the controls as demonstrated by the in-vivo and in-vitro studies. Serum gastrin levels were significantly higher and somatostatin levels were lower in the test group than in the controls. In addition, infected animals showed evidence of gastritis on histological examination. Gastric motility is altered in rats infected with Hh1, a fact possibly related to concurrent abnormalities of gastrin and somatostatin secretion.
\end{abstract}

\section{Introduction}

Helicobacter pylori is the most important cause of gastritis in man and has been associated with peptic ulcer disease and gastric cancer [1,2]. Several factors have been implicated in the pathogenesis of the diseases associated with the micro-organism, such as a decrease in antral somatostatin content and an increase in serum and antral gastrin concentrations observed in $H$. pylori-infected patients $[3,4]$. The mechanism by which $H$. pylori changes gastric hormone metabolism has been only partially elucidated. Possible explanations include alkalinisation of the micro-environment as a result of production of ammonia from urea by $H$. pylori urease, other metabolic noxious products of the bacterium and inflamma-

Received 3 Nov. 1998; revised version received 22 May 1999; accepted 4 June 1999.

Corresponding author: Dr I. Duval-Araujo (e-mail: idaraujo @ medicina.ufmg.br). tion of the antral mucosa induced by the infection that may stimulate $G$ cells or inhibit $D$ cells $[5,6]$.

These hormonal changes may disrupt the complex gastric balance and may affect gastrointestinal motility, as it has been demonstrated that gastrin is a potent motility agonist acting on gastrointestinal smooth muscles, whereas somatostatin has an opposite effect on these muscles [7,8]. However, the association between $H$. pylori infection and alterations in gastric motility is still controversial $[9,10]$. Studies on this subject are scarce, partly because of the lack of an appropriate animal model.

Swine are frequently colonised by a spiral bacterium that was recently shown to belong to the Helicobacter genus by $16 \mathrm{~S}$ ribosomal RNA sequencing and corresponds to $H$. heilmannii type 1 (Hh1), a potential human pathogen $[11,12]$. These spiral bacteria have been observed in the gastric mucosa of patients with gastric symptoms and presenting with histologically 
proven gastritis [13]. The bacterium also seems to be a pathogen in swine, as it is associated with gastritis and peptic ulcer of the pars oesophagea of the pig stomach [14].

Hh1 easily colonises and induces an inflammatory response in the gastric mucosa of infected rodents $[15,16]$, thus providing an experimental model that permits the study of the relationship between gastric spiral bacterium infection and gastrointestinal motility. Therefore, the aim of this study was to evaluate the motor response of the oesophagus and stomach, serum gastrin and tissue somatostatin concentrations, and histopathological alterations in rats experimentally infected with Hh1.

\section{Materials and methods}

\section{Animals}

This work was performed according to international guidelines for animal laboratory care. Twenty 2-4month-old female Wistar rats with free access to water and a commercial pellet diet were used in the study.

\section{Inocula}

Mucus was obtained from the gastric antral mucosa of Hh1-positive and -negative pigs. Mucus from an Hh1positive pig was used only when a large number of tightly spiralled micro-organisms were observed on carbol fuchsin-stained smears. Mucus was considered negative when carbol fuchsin staining, urease test and PCR for Hh1 were negative. One part of the mucus was homogenised in three parts of saline $0.85 \%$ in a vortex blender and then used for rat inoculation. Twenty rats lightly anaesthetised with ether were inoculated via a stomach tube with $0.2 \mathrm{ml}$ of the mucus homogenate as follows: 10 rats with mucus containing $\mathrm{Hh1}$ (test group) and 10 with mucus containing no Hh1 (controls). All rats were maintained under the same conditions in separate cages.

\section{In-vivo motor study [17]}

Fifty-six days after inoculation, the animals were fasted overnight and maintained individually in metabolic cages. They were then anaesthetised with ketamine chloride. Peptone broth $(100 \mu \mathrm{l})$ mixed with $100 \mu \mathrm{l}$ of ${ }^{99 \mathrm{~m}} \mathrm{Tc}$ phytate $(18.5 \mathrm{MBq} / \mathrm{ml})$ was administered by oesophageal cannulation.

Data were collected at one frame each $20 \mathrm{~s}$ for $10 \mathrm{~min}$ in a Siemens Orbiter gamma-camera/Microdelta, fitted with a general purpose collimator. The images were obtained immediately after the radioisotope administration. Fifteen images of the oesophagus and stomach of each animal were obtained during $10 \mathrm{~min}$, at $40-\mathrm{s}$ intervals. The oesophageal area was determined in the first and last images. The radioactivity in the first image corresponded to $100 \%$ and the radioactivity in the last image (Remnant index) was determined by means of proportional calculation; this corresponded to the radioactive material that persisted inside the oesophagus after the end of the study (oesophageal remnant), according to the formula:

$$
\mathrm{ER}=\frac{\mathrm{EL} \times 100}{\mathrm{EF}}
$$

$\mathrm{ER}=$ oesophageal remnant; $\mathrm{EF}=$ Radioactive count in first image; $\mathrm{EL}=$ Radioactive count in last image.

The gastric area was determined by the sum of the oesophageal and gastric areas in the same images, and the radioactivity counted in the first and last images. The total count of the first image was considered to be $100 \%$, and the proportional value was calculated in the last image, according to the formula:

$$
\mathrm{GE}=\frac{100 \times(\mathrm{SF}-\mathrm{SL})}{\mathrm{SF}}
$$

$\mathrm{GE}=$ Gastric emptying; $\mathrm{SF}=$ Radioactive count in first image; SL = Radioactive count in last image.

The difference in proportional value between the first and last images was considered to be the gastric emptying index, i.e., the amount of radioactive material that was left in the stomach at the end of the study.

\section{In-vitro motor study [18]}

After the in-vivo motor study, the animals were anaesthetised with ketamine chloride and a midline laparotomy was performed. Blood samples were collected by puncture of the vena cava and the animals were then killed by aortic section.

The stomachs were separated from the rest of the alimentary tract, opened longitudinally and thoroughly washed with saline $0.85 \%$. Strips of $3 \times 0.5 \mathrm{~cm}$ in length of the gastric wall taken along the greater curvature of the stomachs from the corpus to the antrum were obtained from each animal for the in-vitro motor study. Each tissue was used only once for each group. The fragments were maintained in a nutrient solution containing $\mathrm{NaCl} 17.2 \mathrm{~g}, \mathrm{KCl} 0.43 \mathrm{~g}, \mathrm{CaCl}_{2}$ $0.43 \mathrm{~g}, \mathrm{MgCl}_{2} .6 \mathrm{H}_{2} \mathrm{O} 0.215 \mathrm{~g}, \mathrm{NaH}_{2} \mathrm{PO} 4 . \mathrm{H}_{2} \mathrm{O} 0.1075 \mathrm{~g}$, $\mathrm{NaHCO}_{3} 2.15 \mathrm{~g}$ and glucose $2.15 \mathrm{~g}$ in $2.150 \mathrm{ml}$ of water.

The agonist used in this assay was acetylcholine hydrochloride (Sigma). The method used for study was the construction of dose-response curves to cumulative acetylcholine doses. Successive concentrations of the agonist increasing on a logarithmic scale were added to the perfusion bath containing $10 \mathrm{ml}$ of nutrient solution and the maximal contractile response was recorded after each agonist dose. The next dose was then added without washing the preparation. Thus, a staggered dose-response curve was obtained. The 
first dose capable of inducing a response was considered to be the threshold dose (TD). The greatest contractile amplitude obtained in response to the agonist was the maximal contraction (MC). The affinity of the muscle fibre for the agonist was calculated on the basis of the maximal contraction (pD2). The values obtained for these parameters for each preparation are reported as the median (ranges).

\section{Bacteriological study}

Gastric fragments of the antral and oxyntic mucosa were also obtained and used for carbol fuchsin-stained smears [19], urease test [20], culture and PCR for Hh1. One specimen from each area was smeared on to a glass slide, heat-fixed, stained with carbol fuchsin and examined by oil immersion microscopy for the presence of spiral bacteria. The specimen for the urease test was inoculated into Christensen's urea 2\% agar and examined within $24 \mathrm{~h}$. Specimens for culture were plated on to Belo Horizonte medium [21] and Skirrow's medium and incubated under micro-aerobic conditions at $37^{\circ} \mathrm{C}$ for up to 10 days. Fragments for PCR were held at $-80^{\circ} \mathrm{C}$ until tested.

\section{PCR}

Dissected tissue samples were thawed and suspended in a tube containing $1 \mathrm{ml}$ of PBS. They were centrifuged twice in PBS at $13000 \mathrm{~g}$ for $10 \mathrm{~min}$ and crude DNA was extracted from the resulting pellet as described by Fox et al. [22]. Briefly, the pellet was digested with lysozyme, proteinase $\mathrm{K}$ and other enzymes, and then the DNA was precipitated with hexadecyltrimethylammonium bromide (CTAB). After phenol-chloroform extraction, the DNA was precipitated with ethanol. The pellets were suspended in $50 \mu \mathrm{l}$ of sterile distilled water and DNA was quantified by measuring the optical density at $260 \mathrm{~nm}$.

The PCR was performed in a final volume of $50 \mu \mathrm{l}$ containing Taq DNA polymerase, 25 pmol of each primer, $1.5 \mathrm{mM} \mathrm{MgCl}_{2}, 200 \mu \mathrm{M}$ deoxyribonucleotides (dGTP, dATP, dTTP and dCTP) and $1 \times$ reaction buffer (10 mM Tris- $\mathrm{HCl}, \mathrm{pH} 8.3,50 \mathrm{mM} \mathrm{KCl})$. Amplification cycles were performed in a DNA thermal cycler (PTC$100^{\mathrm{TM}}$, MJ Research Inc.) as follows: denaturation at $94^{\circ} \mathrm{C}$ for $1 \mathrm{~min}$, annealing at $65^{\circ} \mathrm{C}$ for $1 \mathrm{~min}$, extension at $72^{\circ} \mathrm{C}$ for $1 \mathrm{~min}$ ( 30 cycles) and a final extension at $72^{\circ} \mathrm{C}$ for $10 \mathrm{~min}$. PCR-amplified products were electrophoresed in agarose $1 \%$ gel, stained with ethidium bromide and examined under UV light.

The 16S rRNA cistrons were amplified with primers FH1 and FH2 (GenBank accession no. L10079) which were chosen on the basis of the 16S rRNA gene sequence of $H$. heilmannii [23].

\section{Hormonal study}

Blood samples obtained by puncturing the vena cava were used for serum gastrin determination and serum samples were frozen immediately and stored at $-20^{\circ} \mathrm{C}$ until assayed.

Tissue samples of gastric antrum from the lesser curvature were obtained for the somatostatin assay. These fragments were frozen immediately and stored in liquid nitrogen until processed. Hormone was extracted, frozen immediately and lyophilised.

Somatostatin extraction from gastric mucosa. Only specimens weighing $>0.01 \mathrm{~g}$ were used for somatostatin assay. Somatostatin was extracted from the antral mucosa by the method of Bryant and Bloom [24]. Capped 1.5-ml Eppendorf tubes were filled with $1.0 \mathrm{ml}$ of distilled water, placed in a vigorously boiling water bath and left there for $20 \mathrm{~min}$ for temperature stabilisation. The tissue was weighed while thawing and transferred to the tube. Glacial acetic acid $(30 \mu \mathrm{l})$ was added to each tube and mixed. After $15 \mathrm{~min}$ in the water bath, two 300- $\mu$ l samples for somatostatin determination were removed, frozen immediately and lyophilised.

Somatostatin assay. Somatostatin concentration was measured by radioimmunoassay at the Royal Postgraduate Medical School, London, by a slight modification of the method of Williams et al. [25]. Briefly, the samples were reconstituted to their original volume with $0.5 \mathrm{M}$ acetic acid and assayed in duplicate at various dilutions. Antiserum was raised in white rabbits immunised with synthetic somatostatin-14 and used at a final dilution of 1 in 80000 . The antiserum crossreacted fully with somatostatin-28 and showed no cross-reactivity with any known brain regulatory peptides. The assay used iodinated synthetic (Tyr11) somatostatin purified by high-performance liquid chromatography and was done in $60 \mathrm{mM}$ sodium phosphate buffer, pH 7.4, containing $10 \mathrm{mM}$ ethylenediaminetetraacetic acid, $7 \mathrm{mM}$ sodium azide and bovine serum albumin $0.3 \% \mathrm{w} / \mathrm{v}$, with incubation at $4^{\circ} \mathrm{C}$ for 4 days. The bound and free labels were separated after the addition of $6 \mathrm{mg}$ of dextran-coated charcoal (BDH; Norit GSX) in assay buffer containing gelatin $0.25 \%$ and centrifugation for $20 \mathrm{~min}$ at $1600 \mathrm{~g}$. Percentage binding was calculated from the counts from the bound and free labels obtained with a gamma-counter. The assay could detect up to 1 fmol difference between adjacent tubes with a $95 \%$ confidence limit.

Gastrin assay. Gastrin was assayed by a doubleantibody ${ }^{125}$ Iodine radioimmunoassay (Diagnostic Products, Los Angeles, CA, USA). This assay system uses an antibody that can detect active gastrin (G-17 and G$34)$, has very low cross-reactivity with other naturally occurring compounds and has a detection limit of 
c. $12 \mathrm{pg} / \mathrm{ml}$. The assays were done in duplicate during a single session after all samples had been collected.

The values obtained for gastrin and somatostatin concentrations are reported as median (ranges).

\section{Histopathological study}

Specimens of the oxyntic and antral mucosa of the stomach were taken from each animal for histopathological examination. The fragments were fixed in Bouin's fluid for $18-24 \mathrm{~h}$, dehydrated in an alcoholxylene series and embedded in paraffin. Sections (4 mm thick) were stained with haematoxylin and eosin for histological examination. The degree of inflammatory infiltrate was scored as mild, moderate or intense.

\section{Statistical analysis}

The two-tailed $\chi^{2}$ test (histopathological study and microbiological study) and Kruskall-Wallis test (TD, $\mathrm{MC}$, pD2, oesophageal remnant, gastric emptying, antral somatostatin content and serum gastrin levels) were used for statistical analysis. Differences were taken as significant when $\mathrm{p}<0.05$.

\section{Results}

\section{Bacteriological study}

The organism was present in the antral and oxyntic mucosa of all test rats by observation of smears and PCR. The infection was restricted to the stomach in all animals except four, in which small numbers of bacteria were also observed in the duodenum. The pre-formed urease test was also positive (within $3 \mathrm{~h}$ ) in all test animals. Hh1 was not found in the antral or oxyntic mucosa of any control animal. Spiral bacteria morphologically resembling $H$. muridarum and $H$. trogontum were not observed in smears and were not isolated from the gastric mucosa of any animal.

\section{In-vivo motor study}

No significant differences were observed between the test and control groups with respect to the oesophageal remnant, as shown in Fig. 1 (median 56.5\%, range $12.2-99.3 \%$ in test group versus $89.9 \%$, range 24.0 $104 \%$ in control group, $\mathrm{p}=0.06$ ), but a significant increase in gastric emptying was observed in Hh1positive animals when compared with the control group (median $44.2 \%$, range $30.9-70.8 \%$ in control group versus $67.1 \%$, range $45.1-99.9 \%$ in test group), as shown in Figs. 2 and 3.

\section{In-vitro motor study}

Greater gastric contraction was measured in the test group than in the control animals $(p=0.001)$. With

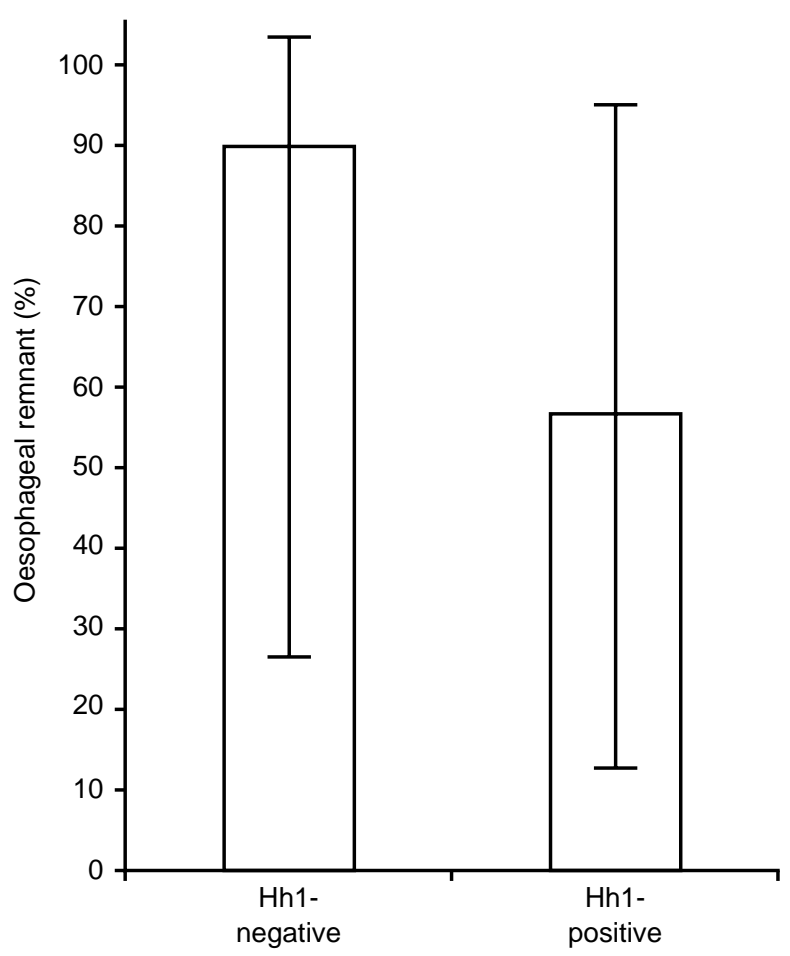

Fig. 1. Oesophageal remnant (\%) in rats negative and positive for Hh1.

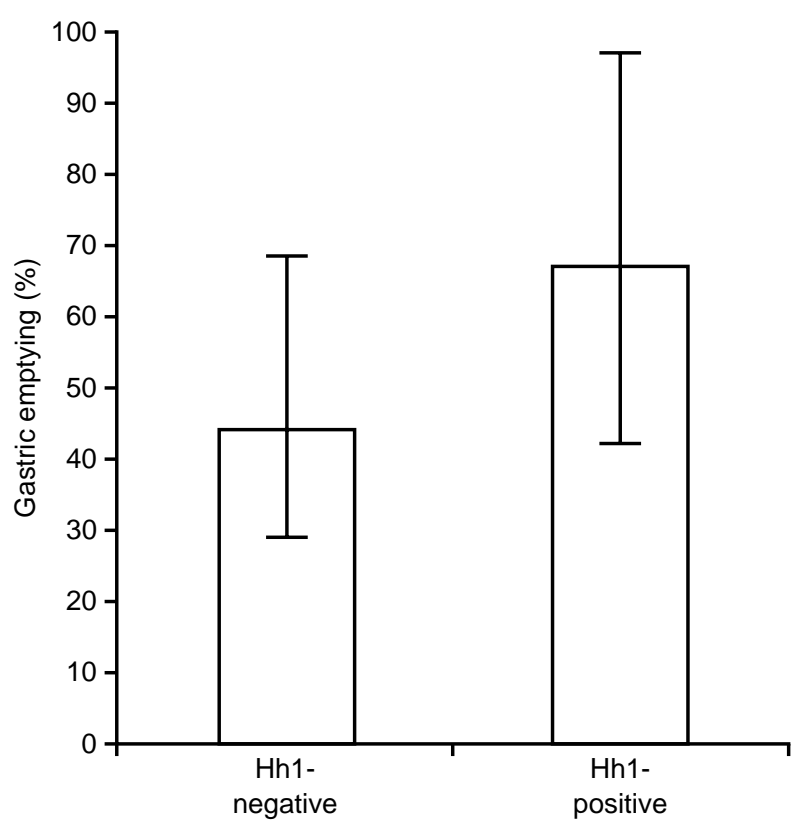

Fig. 2. Gastric emptying (\%) in rats negative and positive for $\mathrm{Hh} 1$.

regard to the TD and affinity of the muscle receptor for the agonist (pD2), no differences were observed between control and test groups (Table 1).

\section{Hormonal study}

The serum gastrin level was significantly higher in the infected animals than in the non-infected animals (median $30.0 \mathrm{pg} / \mathrm{ml}$, range $20.9-84.1 \mathrm{pg} / \mathrm{ml}$ in control 

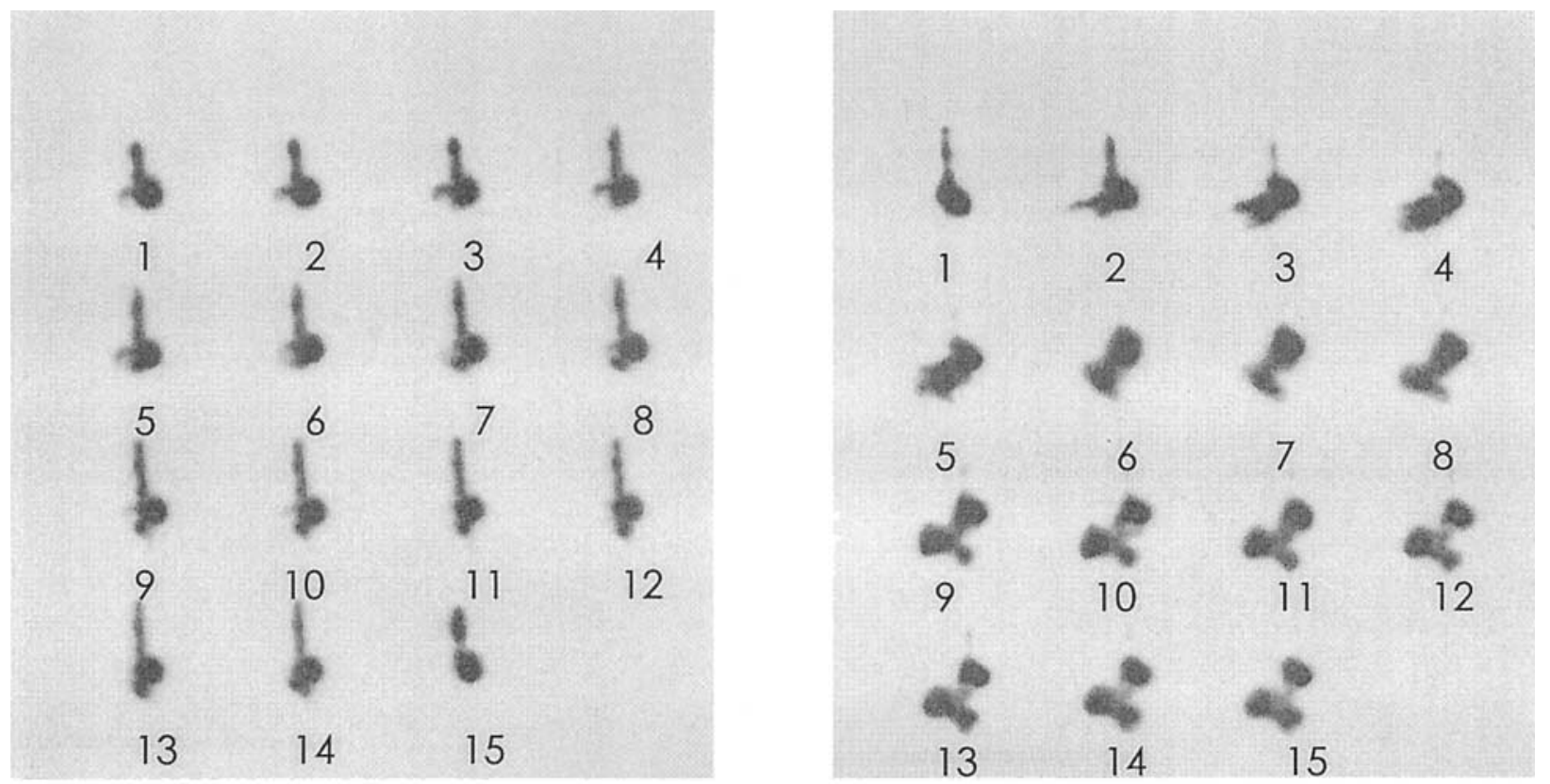

\section{Hhl-negative}

\section{Hhl-positive}

Fig. 3. Gastric emptying scintigraphy in an Hh1-negative and an Hh1-positive rat. 1, first image; 15, last image; each sequence of three images $(1-3,4-6$, etc.) is related to $2 \min$ of study: $1-3,2 \mathrm{~min} ; \mathbf{1}-\mathbf{6}, 4 \mathrm{~min} ; \mathbf{1}-\mathbf{9}, 6 \mathrm{~min} ; \mathbf{1}-\mathbf{1 2}$, $8 \mathrm{~min} ; 1-15,10 \mathrm{~min}$.

Table 1. Threshold dose (TD), maximal contraction $(\mathrm{MC})$ and affinity (pD2) in muscle strips obtained from the stomach of Hh1-positive and -negative rats

\begin{tabular}{lccc}
\hline \multirow{2}{*}{$\begin{array}{l}\text { Test } \\
\text { animal }\end{array}$} & \multicolumn{3}{c}{ Median (range) results } \\
\cline { 2 - 4 } Hh1-negative & $\mathrm{TD}\left(10^{-5}\right)$ & $\mathrm{MC}(\mathrm{mm})$ & $\mathrm{pD} 2$ \\
\hline \multirow{3}{*}{ Hh1-positive } & 0.2 & 3.2 & 2.9 \\
& $0.01-35.0)$ & $(0.1-9.6)$ & $(0.1-8.6)$ \\
& 0.01 & 7.8 & 3.1 \\
& $(0.001-1.0)$ & $(0.1-18.5)$ & $(1.3-4.3)$ \\
& $\mathrm{p}=0.1$ & $\mathrm{p}=0.001$ & $\mathrm{p}=0.9$ \\
\hline
\end{tabular}

group versus $64.3 \mathrm{pg} / \mathrm{ml}$, range $26.7-197.5 \mathrm{pg} / \mathrm{ml}$ in test group, $\mathrm{p}=0.03)$. The antral somatostatin content was significantly lower in the test group than in the control group (median $3.2 \mathrm{ng} / \mathrm{mg}$, range $1.5-9.1 \mathrm{ng} / \mathrm{mg}$ in control group versus $1.0 \mathrm{ng} / \mathrm{mg}$, range $0.5-2.6 \mathrm{ng} / \mathrm{mg}$ in test group, $\mathrm{p}=0.003$ ).

\section{Histological study}

Variable degrees of antral gastritis were observed in the infected animals, ranging from moderate to intense mononuclear and polymorphonuclear cell infiltration, mainly in the lower half of the antral mucosa, but extending through the gastric glands in three animals. The intensity of the inflammatory infiltrate was moderate in four animals and intense in six. Lymphocyte aggregates were observed in four animals. Three bacterium-positive rats had a normal oxyntic mucosa, three presented with mild cell infiltration and four had moderate cell infiltration. There were no inflammatory cells in the antral or oxyntic mucosa of most control animals $(p=0.00001)$. In three rats there were only scarce mononuclear cells in the lower half of the gastric mucosa. Small lymphocyte aggregates were observed in one animal.

\section{Discussion}

H. pylori is considered to be the major agent of gastritis and an essential factor in the pathogenesis of peptic ulcer $[1,2]$. Furthermore, there is increasing evidence that the micro-organism is involved in the genesis of gastric cancer. However, studies concerning the physiological changes caused by $H$. pylori infection have been partly hindered by the scarcity of experimental models that reproduce the major characteristics of human infection in animals. The known hormonal changes induced by the infection may be responsible to a greater or lesser extent for the motor changes of the upper digestive tract, but reports concerning gastric emptying in human subjects with or without $H$. pylori infection are scarce and inconsistent [9, 10, 26-28]. Therefore, the search for an animal model for studies of this type is fully justified. A model has been developed for the study of gastric spiral bacteria infection by using Wistar rats infected with $H$. heilmannii type 1 (Hh1). This bacterium has been 
observed in the gastric mucosa of pigs with peptic ulcer of the pars oesophagea and gastritis [14] and in patients with gastric symptoms and histological gastritis [13]. Therefore, in the present investigation Wistar rats were infected with Hh1 to study the motor changes induced by a micro-organism of the genus Helicobacter. Histopathological alterations, as well as alterations in the concentrations of gastrin and somatostatin possibly implicated in the motor changes, were also studied.

Among the factors that control digestive motility are smooth muscle cells, intercellular connections and the enteric nervous system [29]. Several extra-intestinal controls should also be mentioned, such as the central and extrinsic nervous system, neurotransmitters and the signals emitted by gastrointestinal hormones [30], with gastrin, acetylcholine, gastrointestinal polypeptide (GIP) and motilin being the major agonists [29].

The method for the evaluation of gastric emptying based on the use of radioactive drugs [17] used in the present study has been considered the gold standard in clinical studies, and continues to be the most feasible and the safest method for the study of gastric emptying in human subjects [31]. The method of proportional calculation obtained from the difference between the radioactivity measured at the beginning and at the end of a given period of time in a previously defined area was adopted in the present study because it is one of the methods used for investigations in man. This method confirms whether gastric emptying is delayed or accelerated, but does not reveal the cause of the abnormality, i.e., antral contraction or transpyloric flow [32], with the consequent need for complementary studies for the identification of the factor(s) involved in these changes. Thus, a motor study was performed in vitro to determine the changes in antral smooth muscle contractility that might affect gastric emptying. In the study of in-vitro motility through the evaluation of organs isolated in a bath, the peaks of the electric waves corresponded to the muscle contractions in response to stimulation with the agonist. The technique for the use of cumulative acetylcholine doses recommended by Van Rossum and Van Den Brink [33] provides data about the motor function of the loop in terms of receptors and of the contractile status of the fibres, and is well correlated with in-vivo motor activity.

The present study evaluated gastric emptying in vivo by intragastric infusion of a peptone liquid meal, a stimulus which is believed to provoke gastrin release due to distension, to food collision and to chemical stimulation, and to have a direct stimulatory action on gastric parietal cells [34]. Although it is generally accepted that a test with a solid meal is more adequate than a test with a liquid meal for the detection of abnormalities of gastric emptying [35], examination after a liquid meal is more accurate because it does not depend on the spontaneous participation of the animal in the ingestion of solid particles.

In the in-vivo study, an increase in gastric emptying rate was observed in infected animals, a result that was confirmed by the in-vitro study, in which gastric motility was increased in the same group of animals, as shown by an increase in maximal contraction. These changes may be due to alterations of the gastrointestinal hormones gastrin and somatostatin, the former having an agonist action and the latter an antagonist action on digestive motility. Gastrin acts directly on smooth muscle cells, resulting in contraction, probably by stimulating acetylcholine secretion from the nerve endings and by direct stimulation [36]. Somatostatin mainly acts on acid secretion and gastrin secretion, strongly inhibiting gastrin secretion in the basal and postprandial stages and stimulated by the neural route [37]. It also acts by delaying gastric emptying and by reducing the motility of the small intestine [38], perhaps by inhibiting the normal occurrence of the inter-digestive motor cycle and the electric activity of the stomach and small intestine [36], or by directly or indirectly reducing basal acetylcholine secretion [39]. There is also the possibility that the relaxing response of the stomach results from the secretion of endogenous catecholamines or from a direct action of somatostatin on adrenergic receptors [40].

The present study demonstrated for the first time changes in gastrin and somatostatin concentrations induced by a Helicobacter species other than $H$. pylori. As observed in human patients infected with $H$. pylori $[3,4,41]$, Hh1 induced a significant increase in serum gastrin concentration in rats. The hypergastrinaemia that occurs in $H$. pylori-infected patients may be secondary to a reduction in antral somatostatin levels $[3,4,41]$, as observed in the infected animals. Possible explanations for the reduction in somatostatin concentration in the antrum of $H$. pylori-infected individuals include alkalinisation of the environment as a result of the production of ammonia from urea by the action of the potent urease produced by the bacteria. Also, the action of other toxic metabolites of the bacteria may play a role, as well as the inflammatory response of the antral mucosa induced by infection, which may directly or indirectly inhibit the D cells of the gastric antrum [40]. These same mechanisms may also explain the events observed in the present study, as Hh1 is urease positive and infection with the micro-organism progresses to antral gastritis.

The model of helicobacter infection used in the current study is similar to human infection with $H$. pylori, as both $H$. pylori and $\mathrm{Hh} 1$ are phylogenetically close, both are urease positive and both are involved in the genesis of gastritis and peptic ulcer. Furthermore, changes in gastrin and somatostatin concentrations are observed in infection with the two agents. However, the present results cannot be fully extrapolated to man. For 
example, animals were studied in the early phase of infection and it is not known whether the changes observed in them would be maintained over more prolonged periods of infection. On the other hand, an advantage of the model, which made it possible to observe the changes in motility so clearly, was the fact that all animals had been infected for the same period of time, a condition that would be difficult to evaluate in man, as it would be impossible to determine the length of infection for any given individual.

In conclusion, the present study demonstrated that experimental Hh1 infection of Wistar rats caused alterations in stomach motility characterised by hypermotility. Oesophageal hypermotility was also observed in the test group that was not statistically different from the control group. Among the factors that may separately or jointly contribute to these alterations are changes in gastrin and somatostatin concentrations, and inflammatory changes in the gastric antrum subsequent to infection with the bacteria. However, extensive further studies are needed for a better understanding of the mechanisms responsible for the alteration of gastric physiology observed in infection with microorganisms of the genus Helicobacter.

Financial support was received from $\mathrm{CNPq}$ and FAPEMIG.

\section{References}

1. DeCross AJ, Marshall BJ. The role of Helicobacter pylori in acid-peptic disease. Am J Med Sci 1993; 306: 381-392.

2. Halter F, Hurlimann S, Inauen W. Pathophysiology and clinical relevance of Helicobacter pylori. Yale J Biol Med 1992; 65: 625-638.

3. Queiroz DMM, Mendes, EN, Rocha GA et al. Effect of Helicobacter pylori eradication on antral gastrin- and somatostatin-immunoreactive cell density and gastrin and somatostatin concentrations. Scand J Gastroenterol 1993; 28: 858-864.

4. Sumii M, Sumii K, Tari A et al. Expression of antral gastrin and somatostatin mRNA in Helicobacter pylori-infected subjects. Am J Gastroenterol 1994; 89: 1515-1519.

5. Murakami M, Asagoe K, Dekigai H, Kusaka S, Saita H, Kita T. Products of neutrophil metabolism increase ammoniainduced gastric mucosal damage. Dig Dis Sci 1995; 40: $268-273$.

6. Queiroz DMM, Mendes EN, Rocha GA, Soares TF, Lima GF, Oliveira CA. H. pylori strains possessing cagA and vacuolating cytotoxin producers are associated to both types of gastric carcinoma. Gastroenterology 1996; 110: A236.

7. Walsh JH, Lam SK. Physiology and pathology of gastrin. Clin Gastroenterol 1980; 9: 567-591.

8. Arnold R, Lankisch PG. Somatostatin and the gastrointestinal tract. Clin Gastroenterol 1980; 9: 733-753.

9. Minocha A, Mokshagundam S, Gallo SH, Rahal PS. Alteration in upper gastrointestinal motility in Helicobacter pylori-positive non-ulcer dyspepsia. Am $J$ Gastroenterol 1994; 89: 1797-1800.

10. Pieramico O, Ditschuneit $\mathrm{H}$, Malfertheiner P. Gastrointestinal motility in patients with non-ulcer dyspepsia: a role of Helicobacter pylori infection? Am J Gastroenterol 1993; 88: 364-368.

11. Mendes EN, Queiroz DMM, Rocha GA et al. Histopathological study of porcine gastric mucosa with and without a spiral bacterium ("Gastrospirillum suis"). J Med Microbiol 1991; 35: 345-348.

12. Queiroz DMM, Rocha GA, Mendes EN, Lage AP, Carvalho ACT, Barbosa AJA. A spiral microorganism in the stomach of pigs. Vet Microbiol 1990; 24: 199-204.
13. Solnick JV, O'Rourke J, Lee A, Paster BJ, Dewhirst FE, Tompkins LS. An uncultured gastric spiral organism is a newly indentified Helicobacter in humans. J Infect Dis 1993; 168: 379-385.

14. Queiroz DMM, Rocha GA, Mendes EN, Moura SB, Oliveira AMR, Miranda D. Association between Helicobacter and gastric ulcer disease of the pars esophagea in swine. Gastroenterology 1996; 111: 19-27.

15. Mendes EN, Queiroz DMM, Coimbra RS, Moura SB, Barbosa AJA, Rocha GA. Experimental infection of Wistar rats with "Gastrospirillum suis". J Med Microbiol 1996; 44: 105-108.

16. Moura SB, Queiroz DMM, Mendes EN, Nogueira AMMF, Rocha GA. The inflammatory response of the gastric mucosa of mice experimentally infected with "Gastrospirillum suis". $J$ Med Microbiol 1993; 39: 64-68.

17. Hinder RA, Bremner CG, Horn BKP. A radio-isotope method of measuring gastric emptying, reflux, and secretion. Br J Surg 1972; 59: 903.

18. Weinberg J. Perfusão de órgão isolado com volume constante. Ciência e Cultura 1975; 27: 286-290.

19. Rocha GA, Queiroz DMM, Mendes EN, Lage AP, Barbosa AJA. Simple carbolfuchsin staining for showing C. pylori and other spiral bacteria in gastric mucosa. J Clin Pathol 1989; 42: 1004-1005.

20. Goh KL, Parasakthi N, Peh SC, Puthucheary SD, Wong NW. The rapid urease test in the diagnosis of Helicobacter pylori infection. Singapore Med J 1994; 35: 161-162.

21. Queiroz DMM, Mendes EN, Rocha GA. Indicator medium for isolation of Campylobacter pylori. J Clin Microbiol 1987; 25: 2378-2379

22. Fox JG, Dewhirst FE, Fraser GJ, Paster BJ, Shames B, Murphy JC. Intracellular Campyloribacter like organism from ferrets and hamsters with proliferative bowel disease is a Desulfovibrio sp. J Clin Microbiol 1994; 32: 1229-1237.

23. Cantet F, Magras C, Marais A, Federighi M, Mégrand F. Helicobacter species colonizing pig stomach: molecular characterization and determination of prevalence. Appl Env Microbiol 1999; 65: 4672-4676.

24. Bryant MG, Bloom SR. Measurement in tissue. In: Bloom SR, Long RG (eds) Radioimmunoassay of gut regulatory peptides. London, WB Saunders. 1982: 336-341.

25. Williams G, Ghatei NA, Diani AR, Gerritsen GC, Bloom SR. Reduced hypothalamic somatostatin and neuropeptide Y concentrations in the spontaneously-diabetic Chinese hamster. Horm Metab Res 1988; 20: 668-670.

26. Marzio L, Falcucci M, Ciccaglione AF et al. Relationship between gastric and gallbladder emptying and refilling in normal subjects and patients with $H$. pylori-positive and -negative idiopathic dyspepsia and correlation with symptoms. Dig Dis Sci 1996; 41: 26-31.

27. Murakami K, Fujioka $\mathrm{T}$, Shiota $\mathrm{K}$ et al. Influence of Helicobacter pylori infection and the effects of its eradication on gastric emptying in non-ulcerative dyspepsia. Eur $J$ Gastroenterol Hepatol 1995; 7 Suppl 1: S93-S97.

28. Qvist N, Rasmussen L, Axelsson CK. Helicobacter pyloriassociated gastritis and dyspepsia. The influence on migrating motor complexes. Scand J Gastroenterol 1994; 29: 133-137.

29. Heading RC. Role and integration of mechanisms controlling gastric emptying. Moderator's comments. Dig Dis Sci 1994; Suppl 39: $32 \mathrm{~S}-34 \mathrm{~S}$.

30. Thompson DG. Modulation of gastric perception and motility in man. Current concepts and correlation with symptoms. Dig Dis Sci 1994; Suppl 39: 48S-50S.

31. Vantrappen G. Methods to study gastric emptying. Dig Dis Sci 1994; Suppl 39: 91S-94S.

32. Whitehouse GH, Temple JG. The evaluation of dumping and diarrhoea after gastric surgery using a physiological test meal. Clin Radiol 1977; 28: 143-149.

33. Van Rossun JM, Van Den Brink FG. Cumulative dose-response curves. Arch Int Pharmacodyn 1963; 143: 240-246.

34. Raybould HE, Zittel TT, Holzer HH, Lloyd KCK, Meyer JH. Gastroduodenal sensory mechanisms and CCK in inhibition of gastric emptying in response to a meal. Dig Dis Sci 1994; Suppl 39; 41S-43S.

35. Smout A, Horowitz M, Armstrong D. Methods to study gastric emptying. Dig Dis Sci 1994; Suppl 39: 130S-132S.

36. Walsh JH. Gastrointestinal hormones. In: Johnson LR (ed) Physiology of the gastrointestinal tract, 2nd edn, vol 1. New York, Raven Press. 1987: 181-253. 
37. Konturek SJ, Radeck T, Pusher A, Coy DH, Schally AV. Effect of somatostatin on gastrointestinal secretions and peptic ulcer production in cats. Scand J Gastroenterol 1977; 12: $379-383$.

38. Johansson C, Effendic S, Wisen O, Uvnäs-Wallensten K, Luft R. Effects of short-time somatostatin infusion on the gastric and intestinal propulsion in humans. Scand $J$ Gastroenterol 1978; 13: 481-483.

39. Schrumpf E. The inhibitory action of somatostatin on the stomach. Adv Exp Med Biol 1978; 106: 235-240.

40. Tansy MF, Martin JS, Landin WE, Kendall FM. The differential action of somatostatin on the motor effector system of the canine gastrointestinal tract. Metabolism 1978; 27 (9 Suppl 1): $1353-1357$.

41. Götz JM, Veenendaal RA, Biemond I, Muller ESM, Veselič M, Lamers CBHW. Serum gastrin and mucosal somatostatin in Helicobacter pylori-associated gastritis. Scand J Gastroenterol 1995; 30: 1064-1068. 